\title{
THE HOUSES OF RECLUSE (RECLUSORIA) IN THE URBAN AND SUBURBAN SETTING OF MEDIEVAL DUBROVNIK
}

\author{
Nella Lonza
}

\author{
N. Lonza \\ Zavod za povijesne znanosti HAZU/ \\ Institute for Historical Sciences \\ Lapadska obala 6 \\ HR-20000 Dubrovnik \\ nella.lonza@gmail.com
}

\begin{abstract}
By comparing the reality of medieval Dubrovnik with its European counterparts, the author analyses the space and living conditions prevailing in the Ragusan reclusoria and their urban and suburban setting. Presented on the maps are the data on the foundation of the reclusoria, allowing some conclusions on their development from the first mentions in the thirteenth century to the signs of decline in the fifteenth century.
\end{abstract}

Key words: Dubrovnik, Middle Ages, recluse, churches, urban setting, devotion

Although in medieval Dubrovnik the recluses substantially outnumbered the Franciscan and Benedictine nuns (e.g. at the end of the fourteenth century there were 37 recluses against 24 Poor Claire's and 18 Benedictines), ${ }^{1}$ the scholars have paid hardly any attention to them. Their 'invisibility' is partially due to terminology, i.e. the fact that the documents tend to use the terms recluse, biçoche, piçochere interchangeably, in addition to monache, moniales, and also a range of synonyms denoting their house (reclaustrum, reclusium, eremitorium, conventus, monasterium heremitarum etc.), so that only the context may help distinguish them from the nuns. But that is not the only reason for the oversight: the religious life which developed outside the orders and Church institutions is generally understudied. ${ }^{2}$ Today the recluses are seen as a part of a manifold devotional practice that flourished after the 'birth of the Purgatory', having certain similarities to the movement of beguines and eremitism, yet distinguished by a number of specific features. ${ }^{3}$

Although the recluses appear in the documents as early as $1234,{ }^{4}$ the majority of the entries mention them only generally (e. g. by a bequest of a sum to 'all recluses, inside and outside the city walls'). ${ }^{5}$ More substantial data are supplied by the executions of the wills, ${ }^{6}$ because the beneficiaries of a bequest had to be clearly identified, in the case of the recluses by their name and the location of their reclusorium

\footnotetext{
"This research was supported by the Croatian Science Foundation, grant no. 5106

${ }^{1}$ The data for Poor Claires and Benedictine nuns are of 1397, whereas the data on the recluses are of 1382 (State Archives of Dubrovnik [hereafter: SAD], Distributiones testamentorum [hereafter: DT], ser. 10.2, vol. 2, f. 192v ; vol. 4 , ff. 164v-164ar). Where no specific reference is given in the paper, the conclusion rests on data provided by the same series, vol. 1-30 (1349-1528) and Opera pia, ser. 92, vol. 3, 16 and 20 (regarding the executions of wills by the Treasurers of the Cathedral).

${ }^{2}$ K. GILL, Open Monasteries for Women in Late Medieval and Early Modern Italy: Two Roman Examples, in The Crannied Wall: Women, Religion and the Arts in Early Modern Europe, C. A. MONSON (ed.), Ann Arbor, 1992, p. 15; A. MULDER-BAKKER, Lives of the anchoresses, Philadelphia, 2005, pp. 10-12, 18-19.

${ }^{3}$ On this point, see A. MULDER-BAKKER, Lives of the anchoresses, pp. 5, 12-13.

${ }^{4}$ Codex diplomaticus Regni Croatiae, Dalmatiae et Slavoniae (CD), vol. III, T. SMIČIKLAS (ed.), Zagreb, 1905, p. 402.

${ }^{5}$ The problem is mentioned also in P. L'HERMITE-LECLERCQ, La réclusion dans le milieu urbain français au Moyen $\hat{A} g e$, in Ermites de France et d'Italie, A. VAUCHEZ (ed.), Roma, 2003, p. 159.

${ }^{6}$ The value of this type of documents was noted also by O. REDON, L'espace d'une cité: Sienne et le pays siennois (XIII'-XIVesiècles), Roma, 1994, p. 201.
} 
(e.g. Drasi reclusa Omnium Sanctorum). ${ }^{7}$ The oldest document of the kind dates from 1281 and mentions five reclusoria inside of the city walls and three in the immediate proximity of the city, with a total of 20 recluses. ${ }^{8}$ With the registers, preserved almost in continuity since 1348, the information on the topic becomes more abundant.

\section{THE SPACE OF A RECLUSORIUM}

In the Middle Ages, pious lay women living in cells attached to the churches (recluses, anchoresses, etc.) could be found throughout Europe, yet their communication with the outside world ranged between very restricted and much less so. ${ }^{9}$ Ragusan recluses circulated quite freely, and they maintained lively contacts with their social surrounding, as shown by the court proceedings where they appear in the role of witness. ${ }^{10}$ The freedom of movement and communication was not considered a threat to their devotion, which was supposed to unfold in their 'interior cell' (cellula interior). ${ }^{11}$

Generally speaking, most of the churches had only one reclusorium, and again, most of the reclusoria sheltered only one recluse. However, by the mid-fourteenth century the trend started to change: in 1355 one-third of the sites were occupied by two or three women, ${ }^{12}$ and now and then a community of four to six recluses emerged, ${ }^{13}$ still not changing the predominant practice of living in solitude. Moreover, two reclusoria were built by the same church at times, which shows that the women did not always share their living space. ${ }^{14}$

From elsewhere in Europe we know that the recluses lived in a sort of a small cell that could only be accessed from inside the church. ${ }^{15}$ So far, it is impossible to say whether the same is true of Dubrovnik. Indeed, in a fifteenth-century document the recluse living by the church of St Nicholas at Prijeko mentioned a door in the choir (in choro iuxta portam), ${ }^{16}$ probably destroyed in the reconstruction of $1607 .{ }^{17}$ In general, as the architectonic value of the Ragusan reclusoria was low, they are either unpreserved, ${ }^{18}$ or are so heavily rebuilt that they have lost all of their original features; ${ }^{19}$ in fact, we are able to speak of them only virtually, on the ground of documents. ${ }^{20}$

\footnotetext{
${ }^{7}$ On the same methodological problems see P. L'HERMITE-LECLERCQ, Le reclus dans la ville au Bas Moyen Âge, in Journal des Savants, Paris,1988, p. 223.

${ }^{8}$ Spisi dubrovačke kancelarije, vol. I (Monumenta Ragusina, 1), G. ČREMOŠNIK (ed.), Zagreb, 1951, p. 145. In Siena of the same period (1271) there were 31 urban and suburban reclusoria (O. REDON, L'espace d'une cité, p. 201).

9 P. L'HERMITE-LECLERCO, Le reclus dans la ville, pp. 231-233, 246.

${ }^{10} \mathrm{SAD}$, Lamenta de intus, ser. 51, vol. 1, ff. 39r, 42r, 100r; Lamenta de intus et foris, ser. 53, vol. 1, f. 176r; also the case quoted in: Z. JANEKOVIĆ RÖMER, Maruša ili sudenje ljubavi: Bračno-ljubavna priča iz srednjovjekovnog Dubrovnika, Zagreb, 2007, pp. 117-119.

${ }^{11}$ A. BENVENUTI PAPI, Velut in Sepulcro - Cellane e recluse, in Culto dei santi: Istituzioni e classi sociali in età preindustriale, S. BOESCH GAJANO, L. SEBASTIANI (ed.), L'Aquila-Roma, 1984, p. 376.

${ }^{12}$ DT, vol. 1, ff. 159v-160r; the will is filed in SAD, Testamenta notariae, ser. 10.1, vol. 6, f. 52rv.

${ }^{13}$ Spisi dubrovačke kancelarije I, p. 145; DT, vol. 2, f. 166rv.

${ }^{14}$ Spisi dubrovačke kancelarije I, p. 186; DT, vol. 5, ff. 19v-20r; vol. 14, ff. 193v-194v.

${ }^{15}$ P. L'HERMITE-LECLERCO, Le reclus dans la ville, pp. 231-235.

${ }^{16} \mathrm{SAD}$, Giustizieria, ser. 13, vol. 2, f. 67v. I am grateful to Zdenka Janeković Römer for the photos of the document mentioned in her book Maruša ili sudenje ljubavi, pp. 118-119.

${ }^{17}$ The analysis and reconstruction of Ž. Peković does not bring evidence on this point. Cf. Ž. PEKOVIĆ, Crkva Sv. Nikole na Prijekom, in Starohrvatska prosvjeta (SP), Split, ser. III, 21, 1991, pp.159-170.

${ }^{18}$ For example, it seems that the ruins of the important reclusorium by the church of St Blaise at Gorica, destroyed in the earthquake of 1667, were still there in the mid-nineteenth century, before the stones were recycled for the building of the new church (S. SKURLA, Sveti Vlaho, biskup i mučenik od Sevasta, dubrovački obranitelj, Dubrovnik, 1871, p. 116). ${ }^{19}$ The same probably befell the reclusorium by St Jacobus at Peline (N. GJIVANOVIĆ, Tri veoma stare sačuvane crkvice dubrovačke: 'Sv. Nikola na Prijekom' 'Sv. Jakob na Pelinama' i'Sigurat', in Glasnik dubrovačkog učenog društva 'Sveti Vlaho', Dubrovnik, 1, 1929, pp. 168-169). The very important reclusorium at the church of Transfiguratio Domini was significantly extended after it had become the residence of the nuns of the Third Order (A. BADURINA, Sigurata - crkva i samostan Preobraženja Kristova u Dubrovniku, Dubrovnik, 1986, p. [19]).

${ }^{20}$ On the same problem elsewhere, see P. L'HERMITE-LECLERCO, Le reclus dans la ville, p. 231.
} 


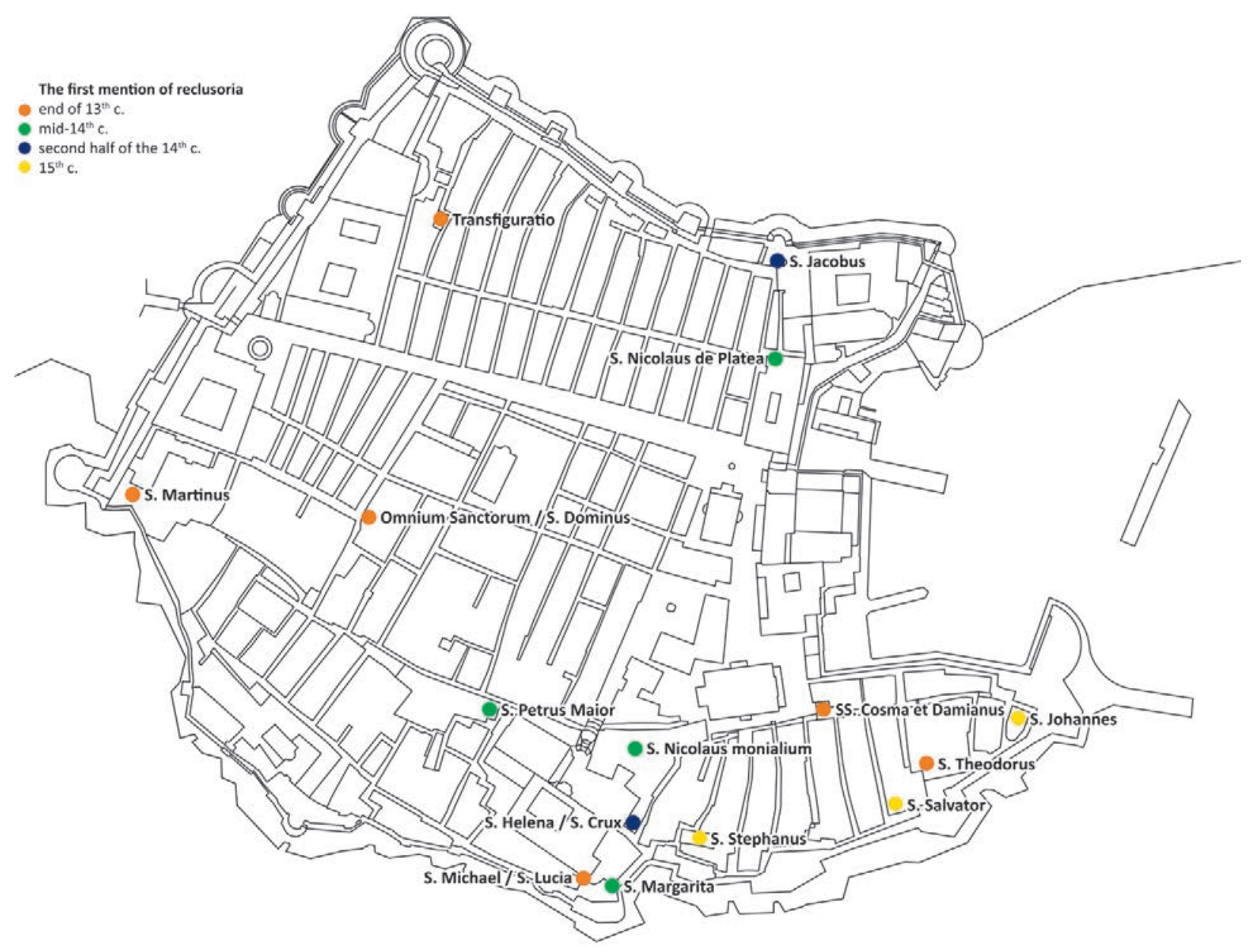

Fig. 1. The setting of reclusoria within the city of Dubrovnik $\left(13^{\text {th }}-15^{\text {th }}\right.$ c.).

One of them regards the construction of a reclusorium by the church of St John in Pustijerna in 1427 (fig. 1), revealing that the building was to be 8 ells wide (ca. 4m) and as long as the church. ${ }^{21}$ Because the church was replaced by a larger one in the seventeenth century, the precise measurements of the reclusorium are unknown, but if we suppose that the church had been only $7 \mathrm{~m}$ long, ${ }^{22}$ it means that the building might have had the ground space of about 28 square metres. We also know that the space of one reclusorium was divided horizontally in 1455 in order to get an extra storey. ${ }^{23}$ Although it is impossible to argue that other reclusoria, particularly those built earlier, were as large as the mentioned examples, it is plausible that extreme restriction of living space was not typical of Dubrovnik, as was of France or Spain. ${ }^{24}$

Some reclusoria, especially if situated outside the city walls, had a small garden to provide for the women's daily needs. This was the case, for example, with the foundation of the church and reclu-

${ }^{21} \mathrm{SAD}$, Acta Minoris consilii, ser. 5, vol. 4, f. 99r.

${ }^{22}$ About 7 metres long were the pre-Romanesque churches of St Nicholas, Sigurata and SS Cosmas and Damian. See I. FISKOVIĆ, Crkvica 'Sigurate' u Dubrovniku - ratom oštećeni te obnovljeni višeznačni spomenik, in Radovi Instituta za povijest umjetnosti, Zagreb, 20, 1996, p. 62; ID., Crkvica Sv. Kuzme i Damjana u središtu Dubrovnika, in Dubrovnik, N.S. 8/4, 1997, p. 266; Ż. PEKOVIĆ, Crkva Sv. Nikole na Prijekom, in SP, 21, 1991, p. 160.

${ }^{23} \mathrm{SAD}$, Diversa cancellariae, ser. 25, vol. 65, f. 16r. Two-storey constructions are found elsewhere, too. See P. L'HERMITE-LECLERCQ, Le reclus dans la ville, p. 234.

${ }^{24}$ A couple of examples cover an area between 5 and 7.5 square metres. See P. L'HERMITE-LECLERCO, Le reclus dans la ville, p. 233. 


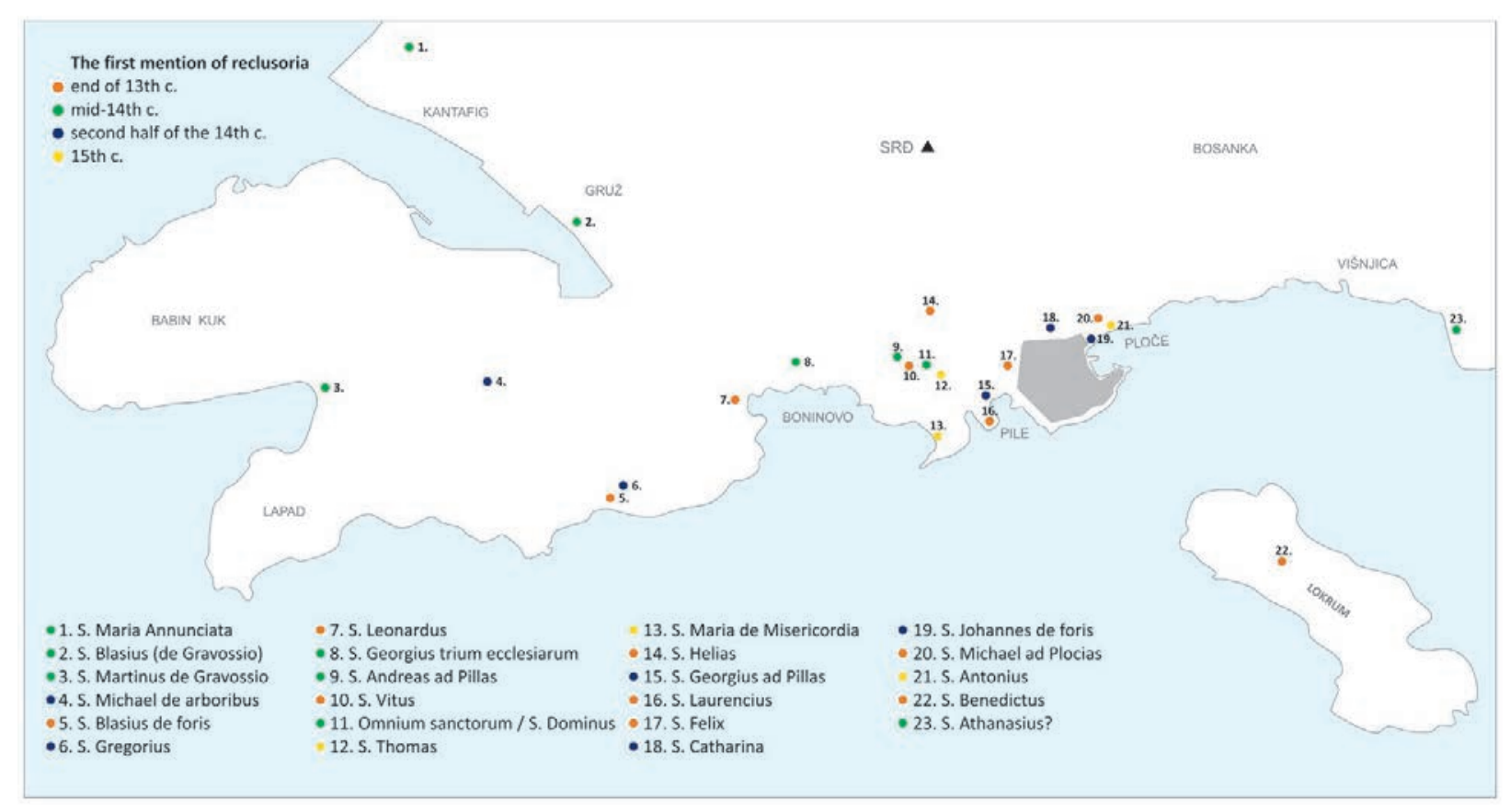

Fig. 2. The setting of reclusoria outside the city walls $\left(13^{\text {th }}-15^{\text {th }} \mathrm{c}.\right)$.

sorium of St Blaise in Gruž (fig. 2, n. 2), commissioned by a patrician Benedict Gondola in 1348 (et quod heremite habeant medium soldum pro orto de terris). ${ }^{25}$

\section{THE WORLD OF RAGUSAN RECLUSORIA}

The research on the reclusoria of medieval Dubrovnik has brought to light the manifold aspects of this devotional practice in terms of the number of the recluses, continuity, social and legal status, etc. ${ }^{26}$

Some houses were known to exist for a very short period of time, as the one by the church of SS Cosmas and Damian mentioned only once, in 1281 (fig. 1), or a reclusorium on the islet of Lokrum, integrated into the complex of an important Benedictine abbey, documented in 1296 (fig. 2, n. 22). ${ }^{27}$ However, the great majority of reclusoria existed in continuity, some of them remaining active at least from the late thirteenth century to the end of the Middle Ages, such as the reclusorium of St Michael out of the Gates of Ploče (Fig. 2, n. 20). There are examples of a reclusorium taking over the place of a monastic community: in the 1350s the recluses inhabited the space of the former Benedictine nunnery of St Nicholas, located near the Cathedral and deserted by 1331 (fig. 1, S. Nicolaus monialium). ${ }^{28}$ But with time, the opposite became a norm, as during the fifteenth and sixteenth century some reclusoria ceased to exist and were replaced by monastic communities ${ }^{29}$ or charitable insti-

\footnotetext{
${ }^{25}$ Testamenta notariae, vol. 3, f. 77rv. The bequest is mentioned by C. FISKOVIĆ, Prvi poznati dubrovački graditelji, Dubrovnik, 1955, p. 65, but with imprecisions.

${ }^{26}$ I leave aside the few reclusoria and heremitoria located farther from the city.

${ }^{27}$ Spisi dubrovačke kancelarije, vol. IV (Monumenta Ragusina 4), J. LUČIĆ (ed.), Zagreb, 1993, pp. 287, 297.

${ }^{28}$ Under that year the nunnery is not listed among the Benedictine convents in Libri reformationum, vol.V (Monumenta spectantia historia Slavorum meridionalium 29), J. GELCICH (ed.), Zagreb, 1897, pp. 310-311, 373; see also DT, vol. 2, f. 52r. The church and the monastery are regularly confused with St Nicholas at Prijeko. Cf. I. OSTOJIĆ, Benediktinci u Hrvatskoj i ostalim našim krajevima, vol. II, Split,1964, pp. 484-485; L. BERITIĆ, Ubikacija nestalih gradevinskih spomenika u Dubrovniku, in Prilozi povijesti umjetnosti u Dalmaciji, Split, 10, 1956, p. 56.

${ }^{29}$ For the Franciscan nunnery of the Holy Apostles (St Peter), see L. BERITIĆ, Ubikacija I, pp. 59-60; Ž. PEKOVIĆ, Crkva Sv. Petra u Dubrovniku, in Radanje prvog hrvatskog kulturnog pejzaža, M. JURKOVIĆ, T. LUKŠIĆ (ed. ), Zagreb, 1996, p. 267.
} 
tutions. For example, in 1535 the old reclusorium by St Theodore, situated in an early urbanised zone in the south-east part of the city (fig. 1), gave place to a women's hospital. ${ }^{30}$ Moreover, the threat of the Ottoman invasion in 1463 proved to be fatal to a series of reclusoria, as the Ragusan authorities deliberated on the demolition of all the buildings in the suburban zone that could be of strategic interest for the enemy. ${ }^{31}$

In terms of legal status, a considerable number of reclusoria were erected by the churches under family patronage (ius patronatus), ${ }^{32}$ the heirs of the founders thus being authorised to appoint the recluse (ius ponendi bizocharas in heremitorio dicte ecclesie), as visible from a document of 1494 on a controversy regarding the reclusorium by the church of All Souls. ${ }^{33}$

It should be emphasised that there was no direct correlation between the importance of the church and the significance of its reclusorium. For example, one of the most significant pre-Romanesque churches was St Peter's (S. Petrus Maior), ${ }^{34}$ although its reclusorium is documented only for 1349-1374, and 1411-1418. The same is true of the church of St Stephen in Pustijerna, whose reliquaries were prized already in the tenth century: its reclusorium is documented only for the period 1404-1442. On the other hand, many reclusoria by the churches of minor importance had a long and prosperous existence, witnessing their own value as a place of devotion.

By far the most important reclusorium within the city walls in the late thirteenth century was the one by the church of All Souls/Domino (Omnium Sanctorum; fig. 1), which housed also a very influential confraternity of flagellants. ${ }^{35}$ The church is documented from 1186 on under the patronage of the Stilo noble family, ${ }^{36}$ but possibly is at least a century older; ${ }^{37}$ it still exists, although heavily reconstructed in 1452, and again after the earthquake of $1667 .{ }^{38}$ Its reclusorium, which in 1281 sheltered an exceptional number of six recluses, remained active until the end of the fifteenth century, but gradually lost its leading position in favour of the one by the church of Transfiguration (Transfiguratio Domini, S. Sigurata; fig. 1). The latter was not particularly large, but its prestige probably rested on the tradition of the church dating from the Late Antiquity, ${ }^{39}$ as well as on the personal charisma of a mid-fourteenth-century reclusa Goina. In the late thirteenth century the reclusorium of St Blaise on the hill of Gorica (fig. 2, n. 5) was just as important, and at the time sheltered not less than five recluses. Its status was probably fed by a custom according to which, prior to embarking upon a long journey and leaving homeland, the Ragusans would visit the church, ${ }^{40}$ which might also indicate that it was better provided by alms and gifts.

\footnotetext{
${ }^{30}$ L. BERITIĆ, Ubikacija, p. 64. On this hospital see T. BUKLIJAŠ, I. BENYOVSKY, Domus Christi in Late-Medieval Dubrovnik: A Therapy for the Body and Soul, in Dubrovnik Annals 8, Dubrovnik, 2004, p. 98.

${ }^{31}$ The demolition of the suburban reclusoria for 'safety reasons' occurred in France, too. See P. L'HERMITE-LECLER$\mathrm{CO}$, Le reclus dans la ville, p. 254.

${ }^{32}$ A similar arrangement existed elsewhere in Europe; ibidem, pp. 239-241.

${ }_{33}$ Document is published in: C. JIREČEK, Der ragusanische Dichter Šiško Menčetić, in Archiv für slavische Philologie, Wien, 18, 1897, p. 75.

${ }^{34}$ On the history of the church, see L. BERITIĆ, Ubikacija, pp. 59-60; Ž. PEKOVIĆ, Crkva Sv. Petra Velikoga: Dubrovačka predromanička katedrala i njezina skulptura, Dubrovnik-Split, 2010.

${ }^{35}$ V. FORETIĆ, Dubrovačke bratovštine, in ID., Studije i rasprave iz hrvatske povijesti, Dubrovnik-Split, 2001, p. 154.

${ }^{36} \mathrm{CD}$, Supplementa I, p. 52.

${ }^{37}$ I. ŽILE, Rezultati arheoloških istraživanja u Domu Marina Držića u Dubrovniku, in Radovi Instituta za povijest umjetnosti, Zagreb, 12-13, 1988-1989, p. 54.

${ }^{38} \mathrm{Ibidem}$, p. 55.

${ }^{39}$ I. FISKOVIĆ, Crkvica 'Sigurate', pp. 59-81.; I. FISKOVIĆ, Tradicije i inovacije u urbanističkome liku starog Dubrovnika, in Dubrovnik, N.S. 5/4, 1994, pp. 105, 116.

${ }^{40}$ Opera pia, vol. 3, ff. 147r, 362v; F. DE DIVERSIS, Opis slavnoga grada Dubrovnika, Z. JANEKOVIĆ RÖMER (ed. and trans.), Zagreb, 2004, p. 144.
} 


\section{RECLUSORIA IN THE URBAN AND SUBURBAN AREA OF MEDIEVAL DUBROVNIK}

Whereas in the late thirteenth century the distribution of all the churches within the city walls might still recall the organisation of the city space of the previous period, ${ }^{41}$ the reclusoria-a relatively 'new' phenomenon, probably not older than the twelfth century-display a quite uniform arrangement on the city map, corresponding to a much more integrated urban space, especially in its southern parts (fig. 1). ${ }^{42}$

Looking at the space distribution of reclusoria in terms of urban vs. suburban ${ }^{43}$ in the whole period under study, it can be noticed that the reclusoria within the city walls were in minority (15 vs. 23), while a half of those outside the city walls (12) were within a negligible distance from the city gates. ${ }^{44}$ As already argued, the recluses' way of life was that of spiritual dedication and not of social isolation. ${ }^{45}$ Some reclusoria, concentrated just outside the city gates (fig. 2, n. 17, 19-21), ${ }^{46}$ may have represented a spiritual 'prophylaxis', preventing 'the danger' from entering the urban space. ${ }^{47}$ Nor is it by chance that the cluster of old reclusoria at Pile (fig. 2, n. 9-12) follows the old communication route to the city, as reconstructed by Igor Fisković. ${ }^{48}$ The same is certainly true of a series of reclusoria following the road to Lapad (fig. 2, n. 5-8).

With the chronological element taken into consideration, there is a clear trend in the fourteenth century of founding the new reclusoria predominantly outside the city walls ( $12 \mathrm{vs.} 6$, whereas at the beginning of the century the ratio was 8 suburban vs. 6 urban). However, in the fifteenth century the number of newly-founded houses in both areas dropped (3), since that period already witnessed a decline of the recluse phenomenon. Three trends played a major role in that process. First, the Franciscans and Dominicans succeeded to propose an attractive alternative through their Third Order. ${ }^{49}$ Indeed, with S. Nicolaus monialium, by the fifteenth-century the process of transformation of the reclusoria into the communities of tertiaries was under way. Second, there was a revival of the Benedictine nunneries, as illuminated by the fact that in the early sixteenth century the number of nuns by ten times exceeded that of 250 years before. ${ }^{50}$ Finally, the new forms of piety, focused on charity, slowly gained place in the wills, ${ }^{51}$ as the testators were more and more inclined to favour 'needy people' over pious women. Such a change of devotion is evident in Dubrovnik, too, since two of its reclusoria had to cede place to the hospitals. After having been a clear mark in the urban setting in the thirteenth and fourteenth century, at the gloaming of the Middle Ages the reclusoria started to disappear or transform, slowly giving way to the institutions of charity which better responded to the altered devotional attitude. ${ }^{52}$

\footnotetext{
${ }^{41}$ See I. FISKOVIĆ, Tradicije i inovacije, pp. 111-113.

${ }^{42}$ On this trend in general cf. ibidem, pp. 116-117.

${ }^{43}$ 'Suburban' is here used in its usual medieval meaning, indicating the territory from Kantafig to the west of the city to the abbey of Višnjica to the east. For the sake of convenience, I leave aside the fact that the city wall was shifted to the north, i. e. to its actual position, shortly after the oldest documented reclusoria.

${ }^{44}$ The reclusoria in thirteenth-century Siena were also concentrated within a radius of $1 \mathrm{~km}$ of the city. Cf. O.REDON, L'espace d'une cité, p. 200.

${ }^{45}$ Cf. also the episode on the sheltering of a criminal priest analysed in: N. LONZA, The Priest Barbius and His Crime Before the State and Church Authorities of Medieval Dubrovnit, in Violence and the Medieval Clergy, G. JARITZ, A. MARINKOVIĆ (ed.), Budapest-New York, 2011, pp. 81, 89.

${ }^{46}$ Cf. O. REDON, L'espace d'une cité, p. 201-204.

${ }^{47}$ The gratitude of the community is echoed in the custom maintained by the secular authorities in giving alms to the recluses on Christmas and Easter. For the years 1331-1332 see Libri reformationum, vol.V, p. 339, 348.

${ }^{48}$ C. FISKOVIĆ, Tradicije i inovacije, p. 105.

${ }^{49}$ P. L'HERMITE-LECLERCO, Le reclus dans la ville, p. 255; A. BENVENUTI PAPI, Velut in Sepulcro, pp. 372-373.

${ }^{50}$ See notes 1 and 52 .

${ }^{51}$ For a shift in piety in the late medieval Pistoia, see D. HERLIHY, Pistoia nel Medioevo e nel rinascimento 1200-1430 (original title: Medieval and Renaissance Pistoia: the Social History of an Italian Town 1200-1430), Firenze, 1972, pp. 272-277. ${ }^{52}$ In 1527 there were 39 recluses and tertiaries (in the document they are listed together), against 286 convent nuns (moniales claustrales), and 115 poor people in the hospitals (DT, vol. 30, ff. 152r-153r, 266v-267v). I wish to thank Mrs. Vesna Baće, who was kind enough to improve the English style of this essay.
} 


\section{ISPOSNIČKI STANOVI (REKLUZORIII) U URBANOM I SUBURBANOM PROSTORU SREDNJOVJEKOVNOG DUBROVNIKA}

Isposnice (recluse) - pobožne žene koje su živjele uz crkve, ali izvan samostanske zajednice - javljaju se u europskim srednjem vijeku s 'rođenjem Ćistilišta' i novim odnosom prema onostranom, koji su promijenili sliku pobožnosti. Premda se spominju u mnogim srednjovjekovnim dubrovačkim oporukama i zapisnicima o njihovu izvršenju (Distributiones testamentorum) te iako su u jednom razdoblju bile brojnije od benediktinki i klarisa, povjesničari jedva da su im poklonili ikakvu pozornost; za to je odgovorna terminološka nedosljednost u izvorima, ali i općenita pojava da su daleko slabije istraženi aspekti vjerskog života izvan strukture crkvenih institucija.

Iz niza vrela vidi se da su dubrovačke isposnice održavale žive društvene kontakte i da se nije smatralo da to proturječi njihovu pobožnom životu. U prostoru rekluzorija ipak je najčešće stanovala samo jedna žena, tek u trećini slučajeva više njih, a izuzetno zajednica od pet ili šest isposnica. Za druge je europske prostore poznato da su isposnice redovito živjele u sitnoj izbi s jedinim ulazom iz crkve. O pristupu rekluzoriju kroz crkvu postoji trag i u jednom dubrovačkom dokumentu, no prostorije isposničkih stanova nisu očuvane - uništene pri kasnijim pregradnjama crkava i zanemarene u arheološkim istraživanjima. Prema arhivskim podacima, barem su neki dubrovački rekluzoriji bili prostrani.

Za dubrovačke rekluzorije tipična je velika raznolikost u broju isposnica, kontinuitetu, pravnom statusu i društvenom ugledu. Istraživanje je pokazalo da ne postoji direktna korelacija između važnosti crkve i snage rekluzorija uz nju. Na primjer, isposnice su samo povremeno živjele uz Sv. Petra Velikog i Sv. Stjepana, dok su dominantni bili isposnički stanovi uz crkvu Svih Svetih (Domino) u gradu te, nešto kasnije, uz Siguratu i Sv. Vlaha na Gorici.

Analiza razmještaja rekluzorija u urbanom i suburbanom prostoru pokazuje da su ovi drugi bili brojniji, ali često smješteni u najužoj okolici. Lokacija uz gradska vrata, osim simbolične zaštite zajednice od opasnosti, kao i niz rekluzorija uz komunikacione pravce, ukazuju također da pobožnost rekluza nije tražila socijalnu izolaciju. Iz kronološke perspektive može se primijetiti da se u 14. stoljeću umnažaju rekluzoriji na izvangradskim predjelima, no već u sljedećem stoljeću rjeđe se osnivaju novi, i u gradu i izvan njega, budući da taj oblik pobožnosti gubi na snazi. Za to su zaslužni procesi unutar redovništva: Tré́i Red franjevaca i dominikanaca postupno preuzima posredničku ulogu koju su ranije imale isposnice, a brojčano znatno rastu i ženske benediktinske zajednice. No, najvažniji je opći pomak u pobožnosti, s izrazitijim usmjeravanjem prema karitativnim ciljevima, tako da i u dubrovačim kasnosrednjovjekovnim oporukama dobrotvornost prema potrebitim članovima zajednice počinje potiskivati milodare za isposnice.

Ključne riječi: Dubrovnik, srednji vijek, isposnički stanovi, crkve, urbanizam, pobožnost 